\title{
GAYA HIDUP PELACUR DI MAKASSAR
}

\author{
Lifestyle of Prostitute in Makassar
}

\author{
Muhammad Irfan Syuhudi \\ Balai Penelitian dan Pengembangan Agama Makassar \\ Jl. A.P. Pettarani No 72 Makassar \\ Email: irfansyuhudi@gmail.com
}

Naskah diterima tanggal 21 Februari 2014. Naskah direvisi tanggal 7 April 2014. Naskah disetujui tanggal 14 April 2014

\begin{abstract}
Abstrak
Tulisan ini ingin mengetahui fenomena pelacur di Makassar. Pelacur bekerja dengan "menjual" tubuhnya untuk dinikmati oleh laki-laki demi meraup uang. Penelitian bertujuan mendeskripsikan kondisi ekonomi pelacur dan apa-apa saja strategi mereka untuk menggaet laki-laki. Pengumpulan data dengan wawancara dan observasi, serta penentuan informan dengan purposive. Penelitian menemukan, kehidupan ekonomi sebagian pelacur di Makassar tergolong sejahtera. Gaya hidupnya pun menunjukkan kategori menengah atas. Ini dilihat dengan barang-barang pribadi yang mereka miliki, termasuk mobil. Strategi yang diterapkan untuk menggaet laki-laki adalah memperhatikan penampilan dengan selalu terlihat cantik dan bergaya. Mereka biasa nongkrong di kafe-kafe dan rumah makan.
\end{abstract}

Kata kunci: pelacur, pelacuran, gaya, tubuh

\begin{abstract}
This paper wanted to know the phenomenon of prostitutes in Makassar. Prostitutes work by "selling" their body to be enjoyed by men for the sake of making money. The study aims to describe the economical conditions of prostitutes and their strategies in attracting the men. The data was collected through interview and observation, and the informants were selected by using purposive sampling tecqhnique. The study found that the economical life of most prostitutes in Makassar is relatively prosperous. Their lifestyle also shows high category. It can be seen from the personal belongings they have, including the car. Strategy adopted to attract the men concerned about the appearance to always look beautiful and stylish. They used to hang out in cafes and restaurants.
\end{abstract}

Keywords: prostitutes, prostitution, styles, body

\section{PENDAHULUAN}

$\mathrm{M}$ ira, sebut saja begitu. Perempuan berusia 21 dan berwajah cantik ini, duduk seorang diri di teras di sebuah kafe di salah satu mall di Kota Makassar. Tangan kanannya sibuk memainkan blackberry keluaran terbaru, yang ditaksir seharga Rp 5 jutaan. Sementara, handphone lainnya, yang ditaksir seharga Rp 3 jutaan, diletakkan di atas meja. Dari dandanan yang dikenakan, mulai pakaian, celana jeans, hingga make up, semua tergolong merek terkenal dan mahal. Bentuk tubuhnya pun proporsional dengan kulit putih dan halus. Rambutnya lurus sebatas bahu. Dalam urusan fashion dan handphone, Mira memang tak ingin ketinggalan. Baginya, bergaya itu wajib terlebih di depan publik. Selain memperlihatkan status sosial, Mira yang berprofesi sebagai pelacur, ingin juga menunjukkan "banderol" dirinya ketika tiba-tiba ada laki-laki yang mendekatinya dan menawarkan untuk transaksi seksual. Ia percaya, gaya dan bentuk tubuhnya dapat mendongkrak tarifnya.

Pelacur identik dengan perempuan. Ketika membincangkan pelacur, maka itu selalu terkait dengan seksualitas. Harus diakui, pembicaraan seksualitas kerap dianggap pembicaraan menyenangkan bagi siapa pun. Kini, dengan kemajuan dan perubahan sosial yang terus 
terjadi, perbicangan menyangkut seksualitas tak lagi dianggap tabu, memalukan, dan dilakukan sembunyi-sembunyi, melainkan telah dilakukan secara terbuka. Adanya rubrik di majalah dan koran yang membahas seputar seksualitas, atau obrolan di radio yang dikemas dalam dialog tanya jawab, menjadi salah satu bukti nyata (Syam, 2010:2). Dengan demikian, ia tidak lagi hanya menjadi konsumsi domestik antara suami dan istri, melainkan telah memasuki wilayah pembicaraan publik.

Secara kultural, pelacur dikonstruksi sebagai perempuan "nakal" yang menempati lembah hitam (Syam, 2010:7). Mereka menyerahkan tubuhnya kepada laki-laki dengan imbalan pembayaran untuk disetubuhi sebagai pemuas nafsu seks di luar pernikahan. Alhasil, beragam julukan diberikan kepadanya. Ada yang menjuluki "penjaja seks" (Ratih, 2005: 342-343), dan juga perempuan jalanan, lonte, dan pekerja seks komersial. Dengan beragam stereotype yang diberikan masyarakat, mereka sesungguhnya adalah kelompok perempuan terbuang dari dunia terang, baik, dan terhormat. Mereka juga korban dari sebuah sistem sosial yang tidak ramah terhadapnya (Syam, 2010:7).

Menariknya, pelacuran sejauh ini belum bisa dihapus. Meskipun beberapa negara ada yang melarangnya, tapi ada juga yang melegalkan. Malah, ada pemerintah yang melarang praktik pelacuran di daerahnya, tetapi toh tetap meminta retribusi atau pajak dari praktik tersebut. Hal ini sesuai dengan apa yang dikatakan M.A.W. Brouwer (1976:115), bahwa pecunia non olet (uang tidak berbau).

Hampir di semua negara di dunia ini dipastikan terdapat pelacur dan praktik pelacuran. Baik yang diorganisir secara rapi dengan melibatkan beberapa orang maupun bekerja sendirian (tanpa mucikari). Maka, tepat apa yang dilontarkan Helen Buckingham, pelacuran merupakan profesi perempuan paling purba. Boleh dikata, inilah profesi pertama seorang perempuan memperoleh penghasilan dengan mengandalkan tubuhnya sendiri demi meraup uang (Ratih, 2005:342-343).

Sekaitan itu, seksualitas merupakan budaya manusia yang tertua. Dengan demikian, usia seksualitas pada hakikatnya setua dengan usia manusia itu sendiri. Di dalam sejarah agama-agama, terutama terkait reproduksi, seksualitas adalah bagian dari proses reproduksi (Syam, 2010:42).

Untuk menaikkan tarif, pelacur tentu perlu bergaya. Artinya, mereka harus mengonstruksi tubuh mereka agar selalu terlihat cantik dan fresh setiap saat. Termasuk para pelacur di Makassar. Jadi, tak heran jika perempuan yang berprofesi seperti ini rutin masuk ke salon. Mereka juga tak segansegan mengeluarkan uang banyak demi perawatan wajah dan tubuh. Mereka tahu betul gaya tidak bisa dipisahkan dari mereka. Semakin berpenampilan menarik dan cantik, itu diyakini ikut mendongkrak tarifnya.

Saat ini, sebagian besar pelacur di Makassar terlihat hidup sejahtera. Mereka tak lagi hidup susah. Secara ekonomi bisa dikatakan hidupnya mapan dan masuk kategori menengah atas. Mereka bisa membeli apa saja yang diinginkan. Di antara mereka itu ada yang bahkan punya mobil dan rumah pribadi. Jika dihitung-hitung, penghasilan mereka dalam sebulan memang tergolong besar, yakni di atas Rp 20 juta.

Sayang, belum ada data pasti mengenai berapa jumlah pelacur di Kota Makassar semua masih estimasi. Masalahnya, tidak semua pelacur ingin mengungkapkan identitas profesi mereka yang sesungguhnya. Apabila ditanya tentang pekerjaan atau profesi, mereka cenderung menyebutkan wiraswasta. Hal ini dapat dimaklumi. Sebab, pelacuran adalah dunia identitas yang tidak transparan (hidden identity), sehingga sangat sulit menemukan data secara pasti mengenai jumlah pelacur yang sebenarnya. Identitas mereka akan selalu dirahasiakan dari keluarga, kerabat, dan masyarakat. Mereka hanya diketahui oleh komunitasnya (Syam, 2010: 86-87). Mereka juga tahu, hampir semua orang menganggap profesi yang mereka geluti adalah hina dan penuh dosa. Karena itu pula, bagi mereka, identitasnya tidak perlu diungkapkan dan diketahui masyarakat.

Dinas Sosial Kota Makassar memperkirakan, pelacur di Makassar pada 2011 berjumlah 800 orang. Mereka yang terdata ini umumnya paling banyak bekerja di tempat prostitusi, seperti di Jalan Nusantara yang terletak di sepanjang jalan menuju arah ke Pelabuhan Makassar. Sejak dulu Jalan Nusantara dikenal menyediakan banyak pelacur. Orang Makassar sering membuat lelucon mengenai jalan ini. Misalkan, "Jalan Kenikmatan" atau "Jalan Vagina Raya”. Di sepanjang jalan ini terdapat bar-bar yang menjual minuman keras dan tempat prostitusi. Khusus bar-bar, pemiliknya menyediakan fasilitas bernyanyi di tempat atau karaoke, sekaligus bisa ditemani perempuan (dampeng) yang disewa per jam. Saat dijadikan dampeng, orang yang menyewa bisa menguasai tubuh perempuan. Sebagai bentuk kuasa tersebut, orang itu bisa memegang dan meraba-raba bagian tertentu tubuh perempuan itu. Perempuan bar umumnya mengenakan rok sangat 
pendek yang memperlihatkan paha serta berbaju tipis tembus pandang. Perempuan di bar juga ratarata merokok dan minum-minuman keras. Namun, tidak semua perempuan di bar berprofesi sebagai pelacur.

Sementara, pelacur yang bekerja di tempat prostitusi bisa langsung "dipakai" di tempat. Meski begitu, ada juga yang bisa dibooking dan dibawa ke tempat lain seusai pulang kerja dini hari. Semua tergantung pembicaraan antara perempuan dengan laki-laki yang tertarik memakai tubuh perempuan itu.

Tulisan ini tidak membahas mengenai pelacur di tempat prostitusi serta yang menggunakan jasa orang lain (mucikari atau teman bencongnya) untuk mencari laki-laki yang mau membayarnya melakukan hubungan seksual. Beberapa pelacur menggunakan jasa teman bencongnya untuk membantu dalam menggaet laki-laki. Bencong adalah sebutan buat laki-laki yang bergaya perempuan dengan tubuh gemulai, tetapi tetap berdandan layaknya laki-laki. Suaranya juga tetap mempertahankan suara khas laki-laki. Bencong ini pada dasarnya berfungsi sebagai mucikari, karena tugasnya mengamati laki-laki yang tengah mencari perempuan untuk berhubungan seksual.

Karena itu, pada saat mereka jalan-jalan, nongkrong, makan atau minum di suatu tempat, bencong inilah yang mencari "mangsa". Matanya terus sibuk memperhatikan setiap laki-laki. Apabila ada laki-laki yang menatap ke arah pelacur yang bersamanya, bencong tadi akan mendekati laki-laki tersebut. Selanjutnya, terjadi percakapan sekaligus transaksi harga. Kalau harganya deal, si pelacur akan memberikan komisi 10 sampai 20 persen dari tarif yang diperoleh kepada teman bencongnya itu. Hubungan pelacur dengan bencong bukanlah hubungan patron klien, tetapi lebih kepada jalinan yang bernuansa simbiotik mutualistik.

Sebaliknya, tulisan ini hanya fokus kepada pelacur yang bekerja sendirian (tanpa menggunakan perantara) atau yang biasa disebut "perempuan panggilan".

Ada dua permasalahan yang diangkat dalam tulisan ini, yakni kondisi ekonomi pelacur di Kota Makassar serta strateginya menggaet laki-laki. Tujuan tulisan ini adalah ingin mendeskripsikan kondisi ekonomi pelacur dan mengetahui apa-apa saja strategi mereka untuk menggaet laki-laki.

\section{Tinjauan Pustaka}

Sudah banyak yang meneliti tentang pelacur. Antara lain, Nur Syam (2010), yang meneliti "Agama Pelacur” di Surabaya. Yang menarik dari penelitian
Syam adalah ia mengamati sisi-sisi religiutas dari pelacur, yang belum pernah diulas oleh peneliti lain. Artinya, meskipun mereka sadar, bahwa pekerjaan yang dilakoni itu perbuatan dosa. Namun, di antara pelacur informannya itu tetap ada yang menjalankan shalat wajib, bersedekah ke rumah ibadah atau ke pengemis, serta berpuasa di bulan Ramadan. Di dalam kegelapan, pasti masih ada sisi terang.

Tulisan lain adalah Joni Lisungan (2007) tentang "Ayam Kampus di Makassar". Penelitian ini juga menarik, karena mengungkapkan perempuan muda yang berprofesi ganda; mahasiswa dan melacurkan diri.

Selanjutnya Agustiawany (2005), yang menulis tentang kehidupan "Babinian Jukung (pelacur kelas bawah di daerah Telawang, Banjarmasin, Kalimantan Selatan)". Perempuan yang berprofesi pelacur itu merupakan cara mereka untuk terus bertahan hidup (survive). Tidak ada pekerjaan yang bisa dilakoni selain melacurkan diri. Tubuh mereka dianggap sebagai kekuatan modal ekonomi untuk mengais uang. Hanya pekerjaan itulah yang bisa dilakukan lantaran tidak memiliki pendidikan dan keterampilan kerja.

Dari beberapa tulisan yang ada, tulisan ini dirasakan berbeda karena ingin melihat gaya hidup para pelacur di perkotaan, khususnya Makassar. Tak bisa disangkal, penghasilan yang mereka peroleh itu cukup mengejutkan, yakni di atas 20 juta per bulan. Tak heran apabila di antara mereka itu ada yang punya mobil, rumah, dan investasi lain di kampung halamannya.

\section{Pelacur dan Pelacuran}

Kartono (2001: 207-211) menyebutkan, ada berbagai motif mengapa orang melacurkan diri. Antara lain, faktor kemiskinan, rendahnya tingkat pendidikan, nafsu seks yang tidak normal, dan sifat konsumerisme yang tinggi tetapi malas bekerja.

Pelacur adalah individu yang memiliki makna implisit sebagai perayaan seksualitas perempuan atas otoritas tubuhnya yang estetis. Pilihan melacur menjadi pilihan yang paling menonjolkan otoritas perempuan terhadap tubuhnya. Di sini perempuan benar-benar bebas memperlakukan tubuhnya, bebas kepada siapa ia mau memberikan tubuhnya, bebas pula dengan siapa ia mau beraktivitas seksual. Ketika perempuan memilih untuk melacur, maka ia lebih bebas mengaplikasikan otoritas tubuhnya. Tidak seorang pun yang dapat memaksa untuk menikmati tubuhnya. Sebaliknya, perempuan itu sendiri yang menentukan tubuh laki-laki mana yang ingin dinikmatinya, dan juga yang bisa menikmati tubuhnya (Ratih, 2005:341-346). Hal ini 
sejalan dengan pemikiran Foucault, bahwa terdapat relasi kuasa dalam hubungan seksual, yakni relasi kekuatan, kepatuhan, ketundukan, hegemoni, dan subordinasi satu atas lainnya (Syam, 2010:43).

Jadi, pelacur merujuk kepada kegiatan individu, personal, dalam hal ini perempuan, yang menjual tubuhnya kepada laki-laki untuk melakukan aktivitas seksual semata-mata. Lakilaki yang merasa terpuaskan dengan berhubungan seksual, kemudian membayar perempuan tersebut dengan uang berdasarkan pembicaraan transaksi sebelumnya.

Sementara itu, pelacuran sendiri sering disebut prostitusi, yang berasal dari bahasa Latin; prostituere atau pro-stauree, yang berarti membiarkan diri berbuat zina. Pelacuran lebih merujuk kepada sebuah tempat atau lokalisasi, yang di dalamnya terdapat pengorganisasian para pelacur. Perempuan yang bekerja di bawah naungan "lembaga" prostitusi cenderung tidak punya kuasa untuk menolak siapa pun laki-laki yang ingin menikmati tubuhnya. Tentu, ini kontras dengan pelacur yang bekerja seorang diri, seperti yang akan diulas pada tulisan ini, yang bebas menentukan atau memilih lakilaki yang bisa menikmati tubuhnya (tanpa adanya tekanan kultural dan struktural dari siapa pun).

Secara etimologis, pelacuran mengandung penilaian hal negatif, karena dianggap sebagai sesuatu yang salah dan telah melanggar aturan atau norma masyarakat. Pelacuran membelit menjadi industri seks yang tak pernah sepi dari keramaian konsumen. Secara post-factum, pelacuran dianggap sebagai penyimpangan moral agama dan norma masyarakat yang sudah merupakan bagian integral dalam kehidupan manusia, berdampingan dengan jalan normalitas (Ratih, 2005:341-342). Dalam bahasa Thomas Aquinas, pelacuran dianalogikan sebagai "selokan" dalam sebuah istana yang megah (Purnomo dan Siregar, 1985:9).

\section{Gaya dan Perayaan Tubuh}

Tentu saja butuh biaya mahal untuk bergaya. Untuk selalu tampil cantik dan terlihat fresh, para pelacur harus rutin masuk salon, membeli pakaian baru, dan membeli handphone keluaran terbaru. Sebagai pelaku budaya, tubuh individu harus membayar mahal ketika mengafirmasi modernitas. Modernitas menyebabkan tubuh harus mengalami pengalaman mahal ketika diekspresikan di ruang publik yang penuh pendisiplinan berdasarkan rasionalitas birokrasi dan kalkulasi ekonomi. (Kadir, 2009: 9).

Selanjutnya, kata Ewen (1990:43-44), gaya itu bermain pada posisi permukaan sebagai tingkah laku. Ia kemudian membagi tiga hal yang mencolok dari gaya pada tubuh modern, yaitu: pertama, gaya berposisi sebagai faktor kritik untuk menilai orang lain dan juga mendefinisikan tubuh sendiri, ketika bertatapan dengan orang lain (baik yang telah dikenal intim maupun asing). Kedua, gaya mempunyai implikasi utama untuk memahami masyarakat. Auranya mempunyai energi untuk melihat perubahan sosial suatu masyarakat. Ketiga, gaya mempunyai kekuatan pembanding untuk menginformasikan bentuk dasar di dalam masyarakat sekaligus mempunyai elemen kesadaran tentang dunia yang sedang dijalani.

Kebanyakan laki-laki yang menjadi pelanggannya atau yang baru pertama kali menggunakan jasanya, terkesan dengan kecantikan wajah, modis, dan bergaya. Karena itu, di kalangan pelacur, terutama yang bekerja sendiri tanpa germo atau mucikari, seperti yang akan dibahas pada tulisan ini, mereka selalu ingin dinilai tidak seronok, kampungan, dan mati gaya. Mereka wajib mengikuti mode yang lagi trend, termasuk di mana mereka nongkrong menunggu laki-laki.

\section{METODE PENELITIAN}

Pendekatan yang digunakan adalah kualitatif, yang menurut Bogdan dan Taylor (Endraswara, 2006:85-86), merupakan prosedur penelitian yang menghasilkan data deskriptif berupa kata-kata tertulis atau lisan dari orang-orang dan perilaku yang dapat diamati. Sebagaimana lazimnya penelitian kualitatif, peneliti dalam hal ini sekaligus merupakan instrumen penelitian.

Pengumpulan data dilakukan dengan wawancara dan observasi (Moleong, 2010:174202 dan Endaswara, 2006a:213-214). Wawancara dilakukan dengan cara santai dan tidak formal di kafe atau tempat makan. Nama-nama informan sengaja dirahasiakan dan digantikan dengan nama samaran atas permintaan mereka sendiri. Suparlan (1988: xvii), menyatakan, apa yang dilakukan ini sesuai dengan kode etik yang berlaku dalam antropologi dan ilmu-ilmu sosial pada umumnya. Tidaklah berarti kalau disamarkan lalu kebenaran dan datanya menjadi diselimuti kabut misteri. Mereka juga mengaku profesinya ini tidak diketahui oleh keluarga besarnya. Pelacur dalam tulisan ini adalah kebanyakan orang Jawa (Jawa Timur dan Jawa Barat), yang tujuan utamanya ke Makassar memang mencari uang dengan cara menjual tubuhnya.

Observasi dilakukan dengan mengamati gaya dan tubuh pelacur ketika sedang mencari laki- 
laki di ruang publik. Observasi dengan sendirinya terhenti ketika pelacur mendapatkan laki-laki, dan kemudian pergi mencari lokasi untuk melakukan hubungan seksual. Biasanya, tempat-tempat yang dijadikan sasaran berhubungan seksual adalah hotel-hotel berbintang yang selama ini dianggapnya aman dari grebek polisi dan masyarakat.

Para pelacur cenderung menolak melakukan hubungan seksual di sebuah rumah atau wisma, meskipun dibayar sesuai tarifnya. Hal ini menyangkut masalah keamanan dan kenyamanan. Dalam menggambarkan realitas sosial tidak hanya bertumpu pada apa yang dikatakan, melainkan memperhatikan apa yang dilakukan. Dengan demikian bukan hanya hasil wawancara, melainkan juga hasil observasi atas tindakan yang dilakukan. Sementara, data sekunder diperoleh lewat penelusuran internet terkait tema tulisan dan Badan Pusat Statistik.

Penentuan informan dipilih secara purposive, yakni mencari dan kemudian memilih orang-orang yang bisa diajak berbicara, dan dari mereka data akan diperoleh (Endaswara, 2006a:206). Penelitian ini memilih pelacur yang berusia di bawah 25 , dengan pertimbangan usia tersebut masih muda dan kebanyakan usia seperti itu juga yang paling banyak dicari oleh laki-laki.

Model analisis menggunakan model interaktif seperti yang diperkenalkan Habermas dan Miles, yakni reduksi data, pemaparan data, dan simpulan melalui pelukisan dan verivikasi. Analisis data berupa pengkajian hasil wawancara, pengamatan, dan dokumen yang telah terkumpul, serta dilakukan secara deskriptif etnografi (Spradley, 1987:35-76, Endraswara, 2006a:215). Dalam hal ini, etnografi boleh disajikan dalam bahasa khayal (imajinasi) seperti halnya metafora (Endraswara, 2006:43).

\section{PEMBAHASAN}

\section{Makassar Prospek yang Menggairahkan}

Sangat sulit mengidentifikasi pelacur hanya dengan sekali melihat. Mereka telah melakukan transformasi atas gaya dan tubuhnya. Mereka yang dulu sering terpaksa berperilaku genit dan berpenampilan seronok untuk menjerat lakilaki, kini sudah menghilangkan kebiasaannya itu. Penampilanluar mereka sama saja seperti perempuan kebanyakan. Begitupula perilaku dan cara bertutur kata. Tidak ada kesan genit dalam gerak-geriknya. Apabila sedang jalan-jalan di tempat keramaian (mall), mereka umumnya bercelana jeans. Hampir tidak ada lagi yang mengenakan rok seperti pelacur di tempat prostitusi atau perempuan bar di Jalan
Nusantara. Sepintas, sulit dibedakan yang mana pelacur dan perempuan baik-baik (bukan pelacur).

Kebanyakan pelacur di Makassar adalah migran asal Jawa. Tepatnya di salah satu kabupaten di Jawa Timur dan Jawa Barat. Tujuan mereka ke Makassar memang untuk mencari uang. Selain untuk memenuhi kebutuhan sendiri, juga untuk membantu ekonomi keluarga di kampung halaman. Tak jarang dari mereka dijadikan tulang punggung keluarga; sebagai penopang perekonomian orang tua dan saudara-saudaranya.

Santi (23), misalnya. Perempuan asal Kota Malang, Jawa Timur, ini pertama kali ke Makassar pada 2007 bersama seorang teman perempuannya yang duluan datang Makassar. Ia tertarik mengikuti langkah temannya itu yang dianggapnya sukses lantaran setiap bulan mengirimi orang tuanya uang Rp 5 juta. Belum lagi, temannya itu telah merenovasi rumah orang tuanya yang sebelumnya cuma berupa rumah kayu (semua berbahan kayu dan tripleks) menjadi permanen (batu).

Santi adalah janda beranak satu. Ia menikah pada usia 19 dan kemudian bercerai, setelah dua tahun mengarungi bahtera rumah tangga. Ia memutuskan bercerai setelah suaminya hampir dua tahun tidak pernah memberinya uang. Suaminya menjadi tenaga kerja di Malaysia. Untuk menyambung hidupnya dan anaknya, ia banting setir dari semula hanya ibu rumah tangga menjadi pekerja.

Sebagai teman dekat, Santi akhirnya tahu apa yang dikerjakan temannya di Makassar. Apalagi, temannya itu berterus terang tentang profesinya sebagai pelacur. Santi awalnya tidak mau. Ia juga tahu kalau profesi itu berdosa. Tapi, lama-lama hatinya pun luluh. Alasannya, ia juga ingin memperbaiki nasib keluarganya. "Kalau saya tidak kerja, siapa yang akan beri kami makan? Saya tidak peduli apa kata orang. Orang-orang tahunya cuma menghina (pekerjaan kami). Saya juga tahu kerja saya ini hina dan dosa. Semua orang tahu itu. Terus terang, saya tidak suka pekerjaan ini. Makanya, saya tidak kasih tahu orang tua dan keluarga di kampung. Mereka tahunya saya kerja di perusahaan swasta. Kalau mereka tahu apa yang saya buat di sini, mereka pasti akan marah besar. Bisa-bisa saya diusir dari keluarga." (Wawancara Santi, 21 Desember 2013, di Makassar)

Selain Santi, ada Mira (21). Kalau Santi berstatus janda muda, Mira lain lagi. Ia belum menikah. Mira, yang ke Makassar atas ajakan temannya, menjadi pelacur lantaran dibohongi oleh pacarnya. Setelah pacarnya merenggut 
keperawanannya, ia pun dicampakkan. Karena frustasi, terlebih pacarnya merantau ke Jakarta dan tidak ada kabarnya lagi, ia pun akhirnya menerima tawaran temannya untuk menjadi pelacur di Makassar. Menurut temannya, Makassar termasuk daerah yang cukup bagus untuk memproduksi uang. Laki-lakinya kebanyakan tidak pelit dan mau mengeluarkan uang untuk kepentingan seksualnya. Selain itu, rahasianya akan terjamin karena jauh dari keluarga.

Membayangkan akan menjadi pelacur membuatnya takut. Sebagai pelacur, ia harus melayani kebutuhan seksual beragam tipe lakilaki. Pertama kali melayani laki-laki, perasaannya bercampur baur. Ada perasaan takut dan jijik karena harus berhubungan seksual dengan laki-laki yang baru pertama kali dilihat dan dikenal. Namun, seusai mendapat bayaran sesuai tarif yang ia pasang, ada perasaan senang di situ.

\section{Kehidupan Ekonomi Pelacur}

Pelacur umumnya mengetahui profesi yang mereka lakoni itu berdosa. Profesi ini juga diakui sangat hina dan memalukan. Karena itu, mereka merahasiakan profesinya dari keluarga. Kepada keluarganya, mereka mengaku bekerja di salah satu perusahaan besar di Makassar. Kalau pun mengirimi uang besar setiap bulan (rata-rata Rp 5 juta) kepada keluarga di kampung, mereka mengaku gajinya memang seperti itu dan terkadang pihak perusahaan memberikan bonus kepadanya.

Lalu, mengapa menjatuhkan pilihan di Makassar? Menurut mereka, laki-laki penikmat seks di Makassar dianggapnya royal mengeluarkan uang. Umumnya, tarif yang mereka kenakan itu dianggap tidak mahal. Apalagi, sasaran mereka adalah kalangan menengah atas, seperti pengusaha, kontraktor, dan pejabat. Untuk sekali berhubungan seksual, tarif yang dipasang minimal Rp 500 ribu. Di bawah harga itu akan ditolaknya. Alasannya, Banyak kebutuhan dan keinginan yang ingin mereka penuhi. Misalkan, perawatan rambut dan tubuh, baju, parfum, celana, handphone, mobil, dan sewa kamar. Gaya dan penampilan juga akan menaikkan tarifnya. Kalau gaya yang mereka tampilkan di depan publik hanya biasa-biasa saja, orang-orang tidak akan tertarik kepadanya. Kalau pun ada yang tertarik, mereka akan dihargai murah.

Bagi yang pernah menggunakan jasa seksual dengan pelacur tersebut, tarif yang dipasang itu sebenarnya tidak terlalu mahal. Apalagi, perempuan itu diakui terkesan bersih dari penyakit kulit dan kelamin. Beberapa laki-laki malah ada yang mengaku pernah membayar Rp 700 ribu sampai Rp 1 juta untuk sekali berhubungan seksual. Dalam hal ini, mereka tidak memikirkan lagi berapa uang yang telah dikeluarkan. Yang penting bisa "menikmati" tubuh perempuan cantik. Mira (21) pun beberapa kali memasang tarif Rp 700 ribu untuk sekali "berhubungan" dan ternyata tidak ditolak.

Dari tarif yang dipasang, wajarlah jika secara ekonomi kehidupan pelacur tergolong sejahtera. Bila dikalkulasi, mereka rata-rata meraih pendapatan sekitar Rp 30 jutaan lebih sebulan. Hitunganhitunganya begini: kalau misalnya mereka melayani tiga orang sehari, dan setiap orang dipasangi tarif Rp 500 ribu, maka dalam sehari mereka bisa mengantongi uang Rp 1,5 juta. Jika Rp 1,5 juta itu dikalikan lagi 23 hari (minus tujuh hari masa haid), pendapatan mereka bisa mencapai Rp 34.000.000 juta! Alhasil, mereka pun bisa hidup dalam kemewahan; ke mana-mana naik mobil pribadi, pakaian dan make up bermerek, dan handphone mahal. Mobil yang mereka miliki pun rata-rata dibeli tunai. antara lain, Honda Jazz, Honda Freed, dan Suzuki Yaris. Mereka juga mengontrak kamar seharga jutaan rupiah per bulan yang dilengkapi berbagai fasilitas (air conditioner, spring bed, televisi, air mandi dingin/panas, dan lemari pakaian). Alasan memilih kontrakan bulanan, karena kalau merasa bosan di tempat itu bisa sewaktu-waktu pindah. Pakaian dan celana kotornya pun dibawa ke laundry.

Mereka pun mengadopsi kebiasaan gaya hidup orang kaya, mulai cara berpakaian, make $u p$, kendaraan, hingga tempat nongkrong. Khusus tempat nongkrong, mereka biasa nongkrong di kafe-kafe atau rumah makan yang biasa didatangi kalangan orang berduit, seperti misalnya, Starbucks, Kentucky Fried Chicken, Mc. Donald, dan Black Canyon. Di tempat ini pula mereka kerap bertemu laki-laki yang mengajaknya "berkencan".

Namun, tidak semua uang itu dipakai untuk memenuhi gaya hidupnya. Paling tidak, setiap bulan, mereka rutin mengirim uang kepada orang tua di kampung halaman, minimal $\mathrm{Rp} 5$ juta. Jumlah ini bisa saja bertambah jika sewaktu-waktu ada keperluan mendadak di kampung. Misalkan merenovasi atap rumah yang bocor, biaya keperluan sekolah saudara atau keluarga.

Meski begitu, mereka juga punya rencana lain di masa yang akan datang. Mereka sepenuhnya sadar tidak selamanya bergelut di profesi ini. Maka, mereka pun menyisihkan penghasilannya dengan menabung. Atau melakukan investasi dengan membeli tanah di kampung, serta perhiasan emas dan berlian. 
Apabila tidak "bekerja", mereka kerap menghabiskan waktu senggang bersama-sama teman-temannya yang juga berprofesi sama. Biasanya, mereka pergi ke salon, fitness, nonton bioskop, atau menyanyi di rumah bernyanyi. Mereka tidak punya hari-hari tertentu untuk "berlibur". Bahkan, terkadang, dalam seharian, mereka sengaja tidak menerima atau mencari laki-laki karena ingin istirahat di dalam kamarnya.

\section{Strategi Memikat Laki-Laki: Harus Cantik dan Bergaya}

Para pelacur ini memiliki strategi untuk memikat laki-laki. Pertama, harus cantik dan memiliki tubuh proporsional. Kedua, selalu berpenampilan menarik dan tidak norak. Ketiga, selalu bersikap ramah kepada (calon) laki-laki. Seperti di sebutkan di muka, untuk mendapatkan wajah dan tubuh proporsional, mereka rutin melakukan perawatan ke salon dan fitness. Dalam sebulan, mereka pasti menyempatkan diri ke salon. Baik itu untuk potong rambut, mengubah model rambut, creambath, facial, luluran, dan sebagainya. Salon yang dituju pun bukanlah salon sembarangan, melainkan salon yang banyak dikunjungi perempuan-perempuan berduit. Sedang fitness, mereka ada yang terdaftar sebagai member.

Tempat yang sering mereka kunjungi untuk mencari laki-laki adalah kafe. Namun, bukan satu kafe saja yang didatangi, melainkan beberapa kafe. Bahkan, dalam sehari, mereka pernah mendatangi dua sampai tiga kali pindah kafe hanya untuk mencari "mangsa".

Setiap kali ke kafe, mereka selalu pergi sendirian. Mereka tidak suka pergi bersama temantemannya, kecuali untuk bersantai. Mereka hanya memesan minuman. Yang sering dipesan adalah juice lemon, juice apel, dan juice sirsak. Sementara kue yang biasa dipesan, antara lain, roti isi keju, brownis, atau black forest.

Para pelacur senang kalau suasana kafe lagi ramai oleh pengunjung laki-laki. Itu menandakan kemungkinan besar ada yang akan mengajaknya kencan. Setelah mengambil kursi kosong, mereka biasanya membuka tas kecilnya yang berfungsi sebagai dompet dan menyimpan handphone. Untuk menyibukkan diri, mereka biasanya sengaja memainkan blackberry-nya. Bagi yang hapal betul tipe-tipe blackberry, mereka pasti bisa menduga blackberry yang tengah dimainkan oleh pelacur itu harganya mahal.

Sambil menunggu orang, tidak semua pelacur merokok. Ada juga yang tidak merokok, karena tidak senang dengan bau asap rokok. Atau, merasa malu kalau pas lagi merokok langsung batuk-batuk. Anggapan bahwa perempuan yang merokok di depan umum identik dengan perempuan nakal, itu hanya pendapat dulu. Sekarang, ada juga perempuan baik-baik tetapi merokok. Ada yang memang senang merokok, ada juga yang merokok dengan maksud menurunkan berat badan.

Ketika nongkrong di kafe, matanya sesekali mengamati laki-laki di dalam kafe tersebut. Kalau matanya kebetulan bertatapan dengan laki-laki, pelacurituyangduluantersenyum. Sebuah senyuman dipercaya bisa sebagai simbol kedekatan. Setelah senyumannya dibalas, ia sengaja menundukkan wajah, seolah tidak peduli, dan kemudian sibuk lagi memainkan handphone-nya di tangan. Dengan begitu, ia ingin membuat laki-laki yang membalas senyumannya tadi menjadi penasaran. Dan, strategi ini dianggapnya selalu berhasil memikat laki-laki. Kalau laki-laki itu serius menanggapi senyumannya, mereka biasanya mendekat dan mendatangi meja si pelacur. Selanjutnya terjadi percakapan sekitar 30 menit yang dilanjutkan dengan transaksi. Kalau harganya deal, mereka kemudian keluar kafe sendiri-sendiri dan bertemu di suatu tempat; hotel berbintang.

Pelacur memilih tempat berhubungan seksual di hotel berbintang untuk menaikkan kelasnya. Menurutnya, ini juga sebanding dengan gaya dan penampilannya. Kalau di wisma atau hotel melati, itu akan menurunkan status sosialnya. Mereka juga merasa malu apabila sesama teman profesinya tahu melayani tamu di wisma atau hotel melati. Selesai melayani laki-laki, mereka biasanya langsung pulang ke kamar kontrakannya. Mereka membatasi waktu sampai pukul 12 malam saja.

Meskipun berorientasi ekonomi, namun mereka ternyata selektif memilih laki-laki. Mereka tidak menerima semua ajakan laki-laki. Artinya, mereka terkadang menolak, meski laki-laki itu mampu membayar. Kalau laki-laki itu dianggap kurang memperhatikan penampilan luarnya atau terlihat tubuhnya kotor, dengan terpaksa akan ditolaknya secara halus. Dalam sehari, mereka membatasi melayani laki-laki maksimal tiga orang saja.

Para pelacur menolak berpacaran dengan laki-laki yang pernah membayarnya melakukan hubungan seksual. Mereka tidak ingin "main hati". Baginya, ini merupakan bisnis dan tidak boleh dicampur dengan perasaan. Terlebih, untuk saat ini, mereka masih fokus mengumpulkan uang sebanyak-banyaknya. Di antara laki-laki itu, ada 
yang pernah mengajaknya pacaran, tetapi dengan halus ditolaknya. Mereka belum ingin terikat dalam sebuah hubungan khusus. Ketika resmi menjalin asmara, ruang geraknya untuk menjadi "perempuan bayaran" pasti terbatasi. Laki-laki yang menjadi pacarnya pasti akan melarangnya lagi menjadi pelacur. Tentu saja, dari segi ekonomi, itu akan merugikannya karena tidak lagi meraup uang dari hasil penjualan tubuhnya.

\section{PENUTUP}

Pelacur merupakan fenomena dan realitas sosial yang telah lama ada di Makassar. Mereka ada karena ada konsumen yang kerap menggunakan jasanya. Pelacur yang beroperasi di Makassar umumnya dari Jawa. Mereka kebanyakan datang atas ajakan teman-temannya di kampung, yang terlebih dulu terjun di dunia ini. Mereka memilih melacurkan diri, karena merasakan miskin dan ingin keluar dari kungkungan kemiskinan tersebut. Dari hasil melacurkan diri, kehidupan ekonomi sebagian pelacur lantas berubah drastis. Mereka menghasilkan uang puluhan juta rupiah per bulan. Mereka pun akhirnya mampu membeli barangbarang mahal, termasuk mobil.

Menariknya, meski beroritentasi uang, mereka juga selektif dalam memilih laki-laki. Artinya, mereka tidak menerima begitu saja lakilaki yang menginginkan tubuhnya (walau sesuai tarif). Mereka sendiri yang menentukan kriteria laki-laki yang boleh dan tidak berhubungan seksual dengannya.

Pada akhirnya, setiap perempuan pastilah tidak pernah memiliki cita-cita ingin menjadi pelacur. Jangankan bercita-cita, membayangkan saja pasti tidak. Oleh masyarakat, pelacur masih dianggap sebagai profesi hina dan penuh dosa. Bahkan, banyak yang menganggap "sampah masyarakat". Pelacur dalam tulisan ini pun tidak pernah mengimajinasikan suatu saat kelak dirinya terjerumus di lembah kepelacuran.

\section{UCAPAN TERIMA KASIH}

Saya mengucapkan terima kasih kepada para informan yang telah meluangkan waktunya untuk kepentingan penulisan ini. Juga, tak lupa pula saya berterima kasih kepada jajaran redaksi Jurnal AlQalam Balai Litbang Agama Makassar yang bersedia memuat tulisan ini.

\section{DAFTAR PUSTAKA}

Abdul Kadir, Hatib. 2009. Bergaya di Kota Konflik. Mencari Akar Konflik Ambon Melalui Gaya Hidup Anak Muda. Yogyakarta. Pustaka Pelajar.

Agustiawany. 2005. Babinian Jukung: Pelacuran Kelas Bawah di Banjarmasin, Kalimantan Selatan. Yogyakarta. Tesis Program Pascasarjana Antropologi Universitas Gadjah Mada. Tidak diterbitkan.

Brouwer, M.A.W. 1976. "Hormatilah Pelacur", dalam Antara Senyum dan Menangis. Jakarta. Gramedia.

Endraswara, Suwardi. 2006. Metode, Teori, Teknik Penelitian Kebudayaan. Ideologi, Epistemologi, dan Aplikasi. Yogyakarta. Pustaka Widyatama.

Endraswara, Suwardi. 2006a. Metode Penelitian Kebudayaan. Yogyakarta. Gadjah Mada University Press.

Ewen, Stuart. 1990. "Marketing Dreams. The Political Elements of Style", dalam Tomlinson, Alan, Consumption, Identity and Style. Marketing, Meanings, and The Packaging of Pleasure. Routledge.

Joni Lisungan. 2007. Ayam Kampus di Kota Makassar. Tesis Program Pascasarjana Antropologi Universitas Hasanuddin. Makassar. Tidak diterbitkan.

Kartono, Kartini. 2001. Patologi Sosial. Jakarta. RajaGrafindo Persada.

Moleong J, Lexi. 2010. Metodologi Penelitian Kualitatif. Edisi Revisi. Bandung. PT Remaja Rosdakarya.

Purnomo, Tjahyo dan Siregar, Ashadi. 1985. Dolly: Membelah Dunia Pelacuran Kasus Kompleks Dolly Surabaya. Jakarta. Graffiti Press..

Ratih, In Bene. 2005. “Perempuan dan Teater”, dalam Teori-Teori Kebudayaan, editor Sutrisno, Mudji dan Putranto, Hendar. Yogyakarta. Kanisius.

Spradley, James P. 1987. Metode Etnografi. Yogyakarta. PT Tiara Wacana.

Suparlan, Parsudi (Kata Pengantar). 1988. Kisah Lima Keluarga. Telaah-telaah Kasus Orang Meksiko dalam Kebudayaan Kemiskinan. Judul asli: Five Families, Mexican Case Studies in the Culture of Proverty, diterjemahkan Rochmulyati Hamzah. Jakarta. Yayasan Obor Indonesia.

Syam, Nur. 2010. Agama Pelacur. Dramaturgi Transendental. Yogyakarta. LKiS. 